\title{
COMPARISON OF MORPHOLOGICAL AND ANATOMICAL PROPERTIES OF ENDANGERED ENDEMIC IRIS PAMPHYLICA AND I. MASIA IN TURKEY
}

\author{
N. KANDEmir ${ }^{1}$ and A. ÇELIK ${ }^{2}$ \\ ${ }^{1}$ Department of Biology, Education Faculty, Amasya University, Amasya, Turkey \\ ${ }^{2}$ Department of Biology, Art and Science Faculty, Pamukkale University, Denizli, Turkey \\ E-mail: toygar09@hotmail.com
}

(Received 17 January, 2017; Accepted 20 June, 2017)

In this paper, morphological and anatomical properties of Iris pamphylica and Iris masia were compared and the degrees of relationship among them were determined. Also, morphological and anatomical properties of the two subspecies (I. masia subsp. masia and I. masia subsp. dumaniana) of I. masia were detected. I. pamphylica and subsp. dumaniana are endangered endemic geophytes of Turkey. Morphological properties of various organs of the taxa such as scape, bulb, rhizomes, leaves, flowers, fruit and seeds were given. Subsp. dumaniana is separated from subsp. masia with the differences of falls, standards, colour styles and vein colours. In anatomical studies, cross-sections of roots, scapes, leaves and surface sections of the leaves of these taxa were taken. Some different (the structure of pith region and xylem strands numbers in the roots, vascular bundles and micropapilla status in the scapes, leaf outline structure, the presence of sclerenchyma cap at phloem poles of vascular bundles in the scape, extends to both epidermis of sclerenchyma cap, absence and presence of keels, layer numbers of palisade and spongy parenchyma and the presence of bulliform cells in the upper epidermis of leaves) and similar characters (three-sided thickening of the endodermal cells, stomata and mesophyll types, there is sclerenchyma cap in the vascular bundles of leaf and at the corner of the leaf, there is sheath bundle around the vascular bundles, the cells in the centre of mesophyll and crystal types and there are two rows of the vascular bundles in the mesophyll) were found. Length and width of stomata in the upper and lower surfaces of leaves were measured and stomata index were calculated. The leaves of taxa have xeromorphic structure. Many differences were seen in the anatomical and morphological characters of I. masia subsp. dumaniana. So, it was suggested that I. masia subsp. dumaniana might be upgraded to the species category.

Key words: anatomical, Iris masia, Iris pamphylica, morphological, relationship, Turkey 


\section{INTRODUCTION}

Iridaceae is a large family containing important geophytes in Turkey and in the world. Iris L. is one of the most diverse and well-known genus in Iridaceae. It comprises over 300 species in the world and 56 taxa (50 species, 3 subspecies and 3 varieties) in Turkey, respectively (Güner 2012, Mathew 2001). This genus is known for its unifacial and isolateral ensiform leaves, petaloid style branches, colourful flowers with three stamens, with three horizontal falls and three erect standards (Kandemir 2015, Rudall 1994, Wilson 2011, Wilson et al. 2016). Iris species have essential oils, attractive flowers, and have been used as ornamental and medicinal plants since ancient times. Moreover, chemical compounds in the root of some Iris species are used in dropsies, anti-spasmodic, emmenagogue, stimulants as diuretic, aperients, gall bladder diseases, in fever and enlargement of the liver, for catarrhal ailment of children (Rahman et al. 2003).

The investigated taxa are placed in Hermodactyloides Spach and Limniris (Tausch) Spach subgenera. I. pamphylica Hedge is the largest member of the subgenus of Hermodactyloides and is an endemic East Mediterranean element. It has a limited distribution between Manavgat-Akseki (Antalya) and is known as Akseki navruz (Antalya-Turkey). I. pamphylica is an interesting species with a perigon tube of $2 \mathrm{~cm}$ in length, quadrangular leaves and a flobby capsule. This species can provide economical income as a valuable ornamental plant for the future of Turkey, since it is an attractive species with showy purple flowers. Because of various impressions (human effects, consuming of its flowers by sheep and shepherds, grazing, expansion of agriculture areas and dam construction), this species is under threat of extinction in Turkey (Deniz et al. 2015, Kandemir 2015). Limniris is one subgenus of beardless irises without hair on the falls. I. masia Dykes is also in the Limniris subgenus and Syriacea (Diels) Lawrence series. Having rhizomes, it is a perennial plant and is known in Turkey, as the "Barbed iris". It is one of the just two species in the Syriaceae series according to Mathew (1989). I. masia was divided into two subspecies as subsp. masia and subsp. dumaniana. I. masia Dykes subsp. dumania$n a$ Güner was found in 2012 and was published in Turkey plants list (Güner 2012). Subsp. dumaniana grows in woody region on limestone soils and only in the vicinity Serik (Antalya) in Turkey. So subsp. dumaniana is known as Serik navruz (Antalya-Turkey). I. masia Dykes subsp. masia distributes only in Karacadağ and its surrounding areas. Subspecies masia grows in meadow, pastures and steppes and is non-endemic plant in Turkey. But, it has restricted distribution in Turkey. While subsp. masia is Irano-Turanian element, subsp. dumaniana is an endemic East Mediterranean element.

There are some relationship problems among subgenera of Iris genus. The relationships among species belonging to different subgenus of Iris ge- 
nus were explained with morphological properties and phylogenetic studies by some researchers (Guo and Wilson 2013, Rodionenko 1987, Wilson 2009, 2011, 2014, Wilson et al. 2016). Phylogenetic studies on Iris taxa were carried based on chloroplast sequence data. Although Rodionenko (1987) reported the subgenera (Iris, Hermodactyloides, Scorpiris and Xiphium) as distinct genera, he considered it as a monotypic subgenus Pardanthopsis within Iris genus. According to the chloroplast sequence data, Wilson (2004) recognised as polyphyletic subgenera Limniris and Iris. However, he could not resolve the problems of subgenera of Nepalensis and Xiphium, because these two subgenera were represented with one species. On the other hand, the reticulatas (subgenus Hermodactyloides), the junos (subgenus Scorpiris) and the xiphiums (subgenus Xiphium) are relatively close relatives within the genus Iris. Morphological and anatomical characters and pollen morphology of I. pamphylica is different from those of the species of Hermodactyloides subgenus (Kandemir 2015, Mathew 1989, Rudall 1994). These researchers reported that pollen morphology and morphological characters of I. pamphylica and I. masia are similar to each other. The pollen morphology of I. pamphylica shows similarities not only to that of I. masia but also to the other taxa of Limniris subgenus (except I. lazica and I. unguicularis). Considering this, Mathew (1989) suggested that I. pamphylica provided a connection between subgenera of Hermodactyloides and Limniris. The objective of this study is to unravel evolutionary relationships between subgenera Limniris and Hermodactyloides and to determine the taxonomic significance of anatomical and morphological characters.

\section{MATERIAL AND METHODS}

The materials of Iris pamphylica and I. masia were collected from their habitat during the flowering period in March and May 2015. The localities of plant samples collected are listed below.

Iris pamphylica - C3 Antalya: Beşkonak-Düzağaç Village, Kızılca district, rocky places, 850-900 m, 14 March 2012, Kandemir (440). - C5 Mersin: Find1k Pinar Plataeu-Akarca Güzlesi village, roadside and open forest, 900-1100 m, 9 May 2012, Kandemir (441).

Iris masia subsp. masia - C7 Şanlıurfa: Siverek, Karacadağ, $2 \mathrm{~km}$ from Atlica K. to Avurtepe K., fields margins, at 1100 m, on 10 May 2015, Kandemir (600). - C6 Gaziantep: 30 km S of Gaziantep on Kilis road, at 750 m, 11 May 2015, Kandemir (601).

Iris masia subsp. dumaniana - C3 Antalya: Serik, above Kocayatak town cemetery, woody areas on limestone, roadsides, at 20 m, on 27 March 2015, Çelik (602).

Taxonomic description of the taxa were made according to Mathew (1984) and Güner (2012). Fresh plant samples were fixed in 70\% alcohol solution. 


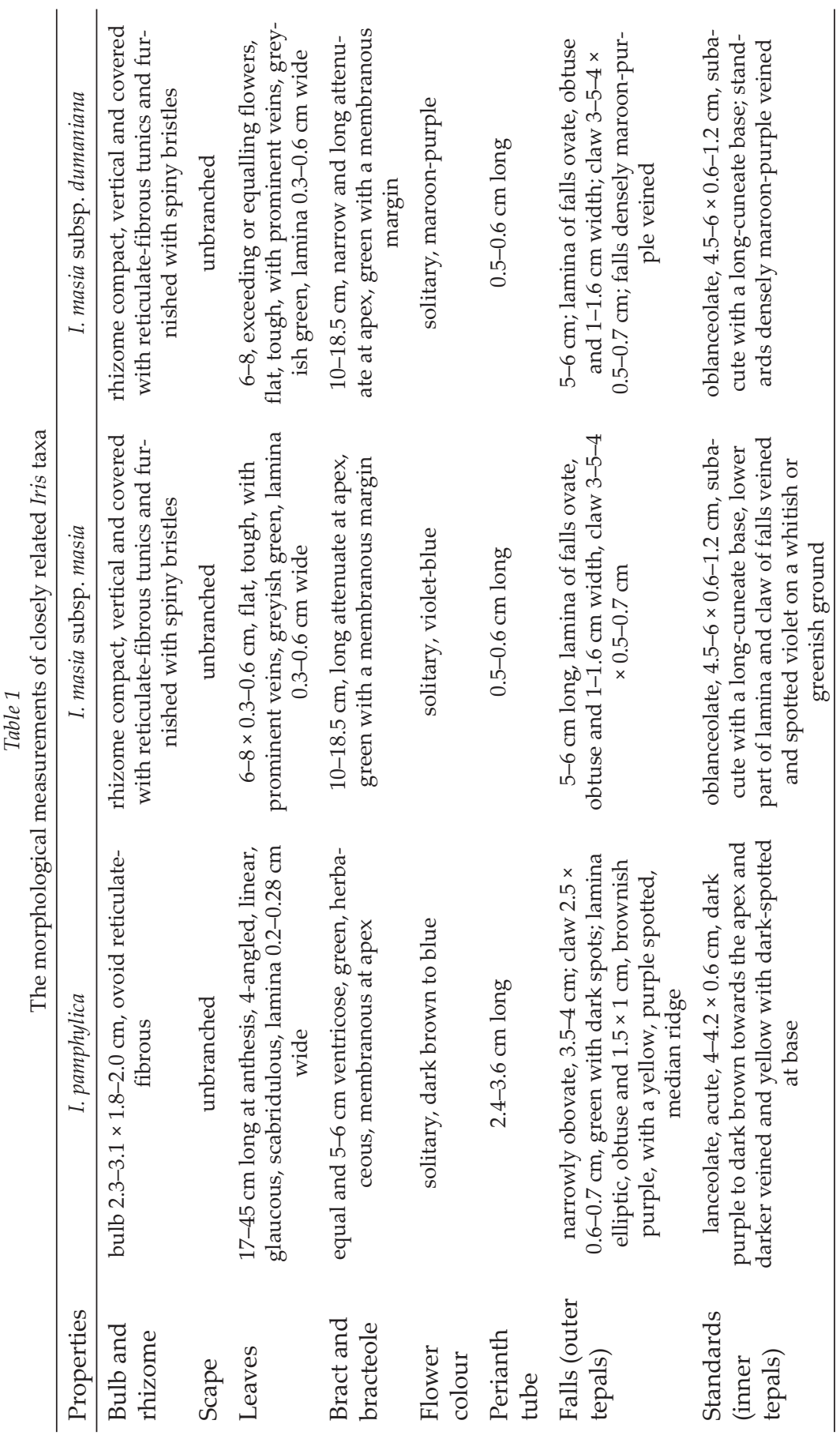



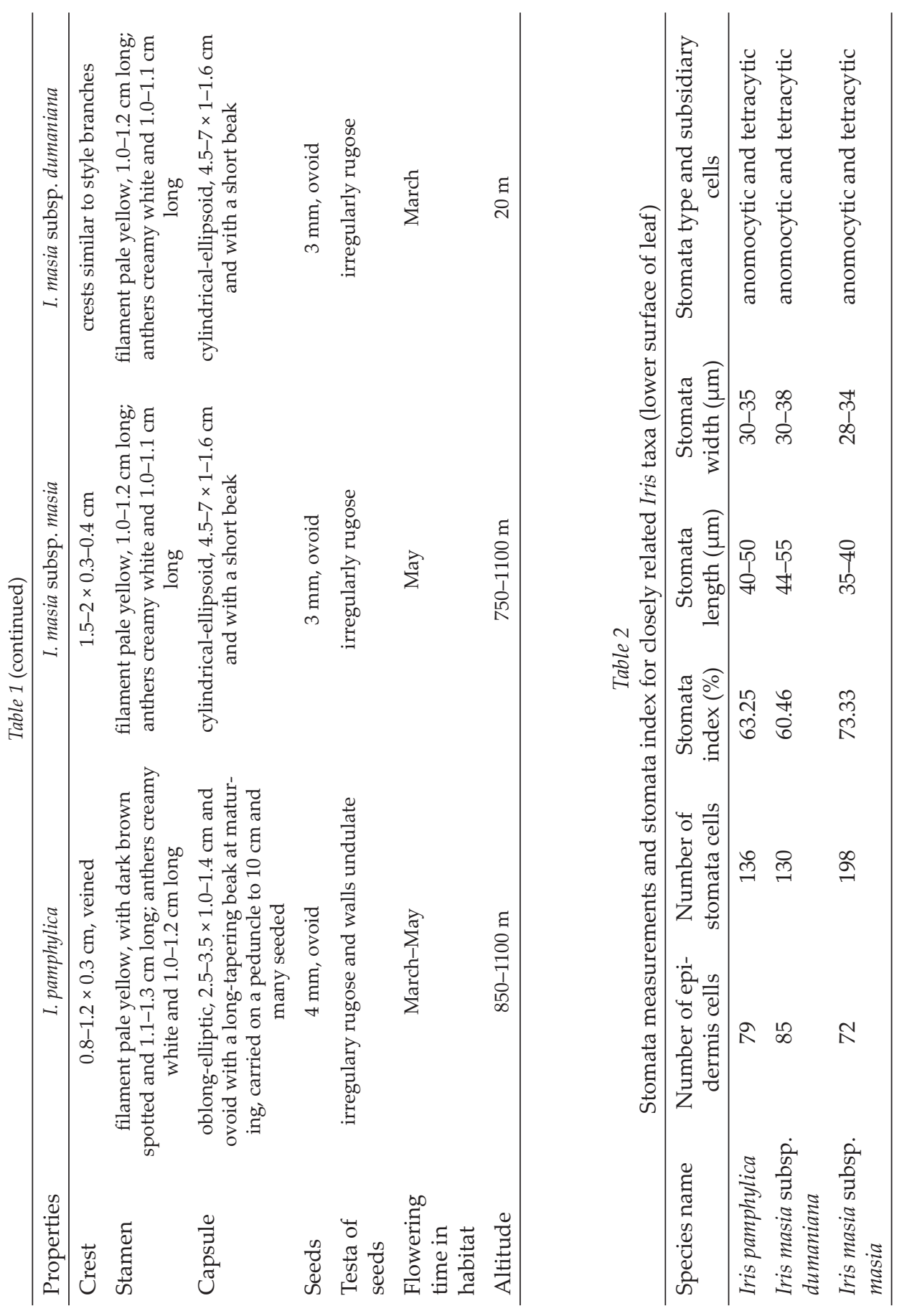


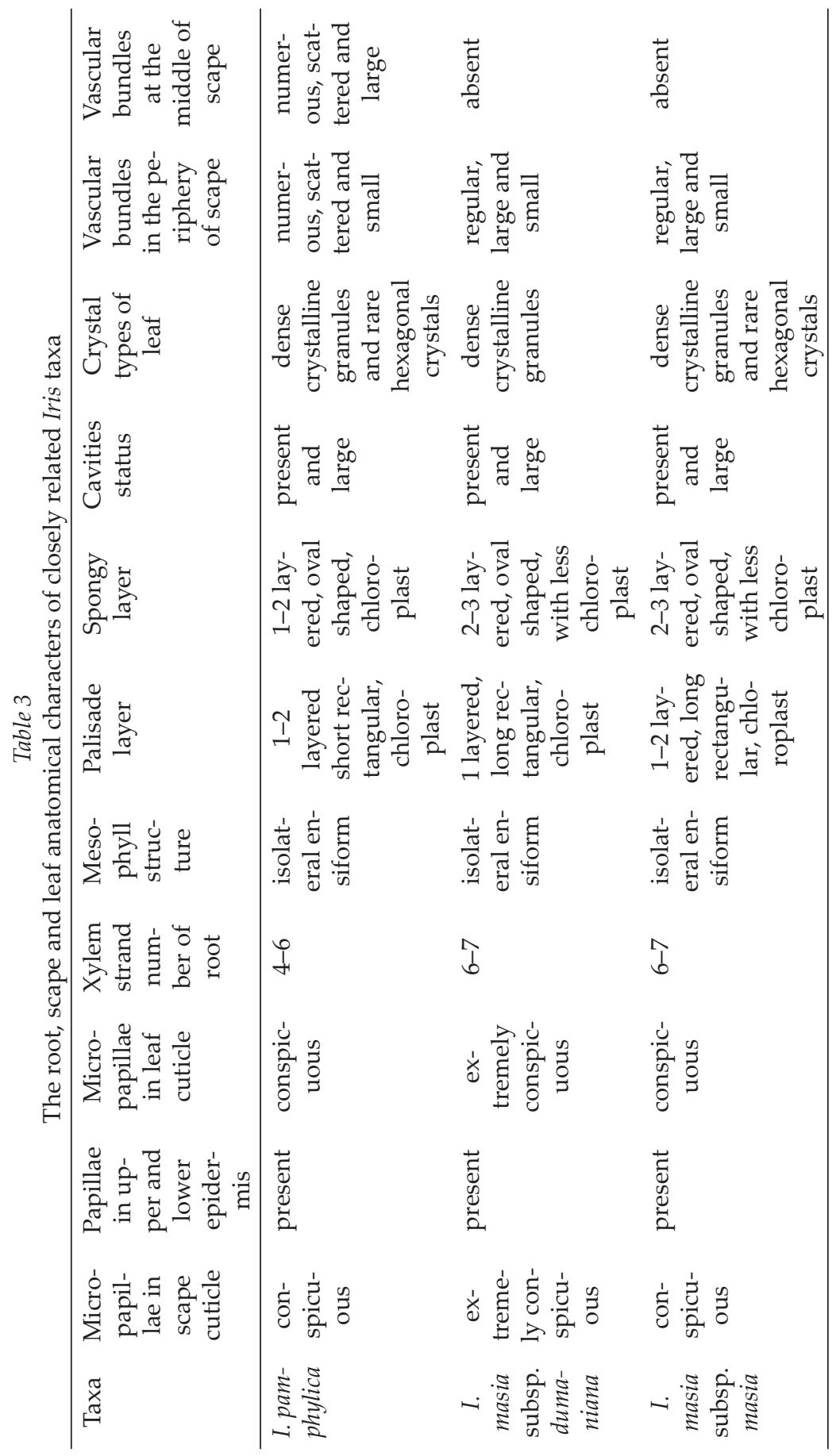


Anatomical investigations were carried out on samples preserved in $70 \%$ alcohol solution. Paraffin method was used for preparing cross-sections of the root, scape and leaf parts (Algan 1981). The cross and surface sections of these parts were photographed. The morphological measurements were made with a micrometric ocular and ruler. The measurement results of morphological characters were given in Table 1. Eleven anatomical characters of the leaf, root and scape (micropapillae in cuticle of scape and leaf, papillae in upper and lower epidermis of leaf, mesophyll structure, the layer number of palisade and spongy parenchyma, vascular bundle types, cavities status, type of crystals, vascular bundles in the periphery of scape and vascular bundles in the middle of scape, xylem strand number of root) were used for relationships of investigated taxa (Table 3). Means of epidermal and stoma cell numbers in $1 \mathrm{~mm}^{2}$ of surface section were determined. Stomata index was calculated according to the description of Meidner and Mansfield (1968). Length and width measurements of stomata in the lower surfaces of leaves were made (Table 2).

\section{RESULTS}

The morphological properties of the Iris taxa

Iris pamphylica: Bulbous perennial and $15-25 \mathrm{~cm}$ in the flowering period. Bulb produces a few small bulblets. Leaves $17-45 \times 0.2-0.28 \mathrm{~cm}$ at anthesis
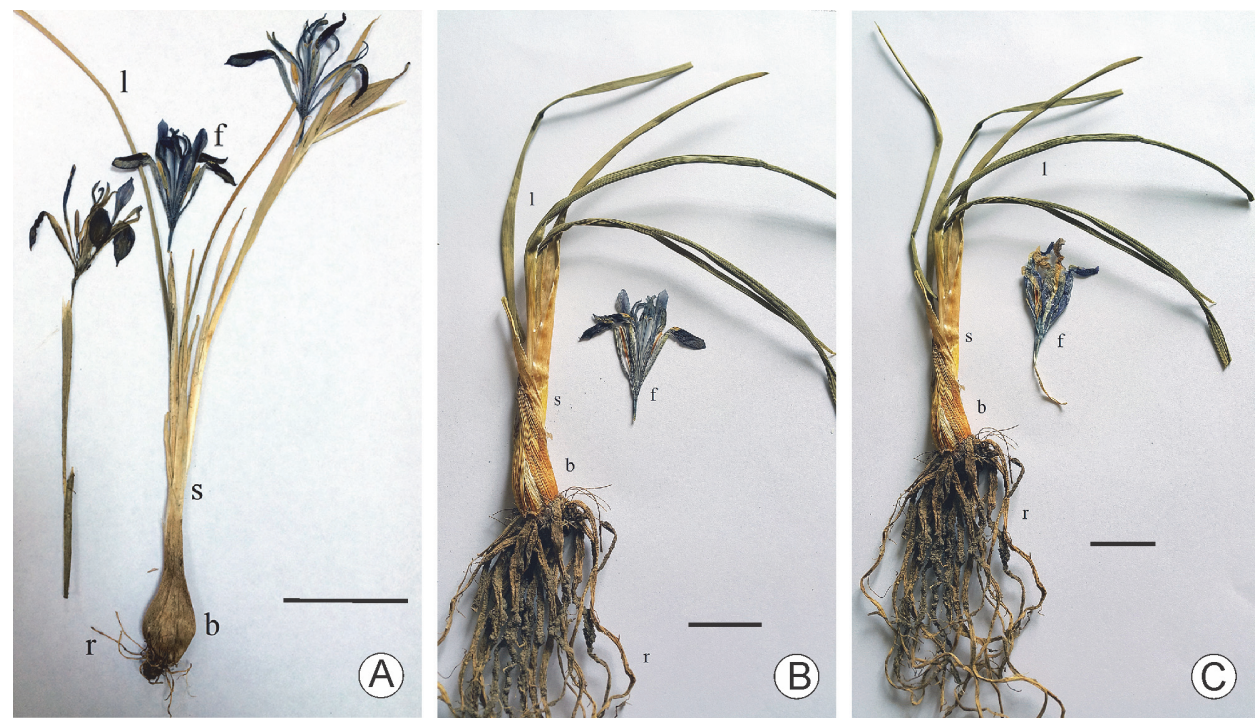

Fig. 1. General appearances of herbarium samples of closely related Iris taxa. $-\mathrm{A}=I$. pamphylica, $\mathrm{B}=I$. masia subsp. dumaniana, $\mathrm{C}=\mathrm{I}$. masia subsp. masia $(\mathrm{r}=\mathrm{root} ; \mathrm{b}=\mathrm{bulb} ; \mathrm{s}=\mathrm{scape}$; $\mathrm{l}=$ leaf; $\mathrm{f}=$ flower $)$. Scale bars for all $=3 \mathrm{~cm}$ 
and elongating later to $75 \mathrm{~cm}$ (Fig. 1A, Table 1). They 4-angled. Bracts and bracteoles closely sheathing perianth tube. Flowers solitary, dark brown to blue and carried on a stem (unlike other species in the subgenus). Falls narrowly obovate, standards lanceolate, acute. Style branches lanceolate, acute lobes. Filaments dark brown spotted and anthers creamy white. Capsule ob-
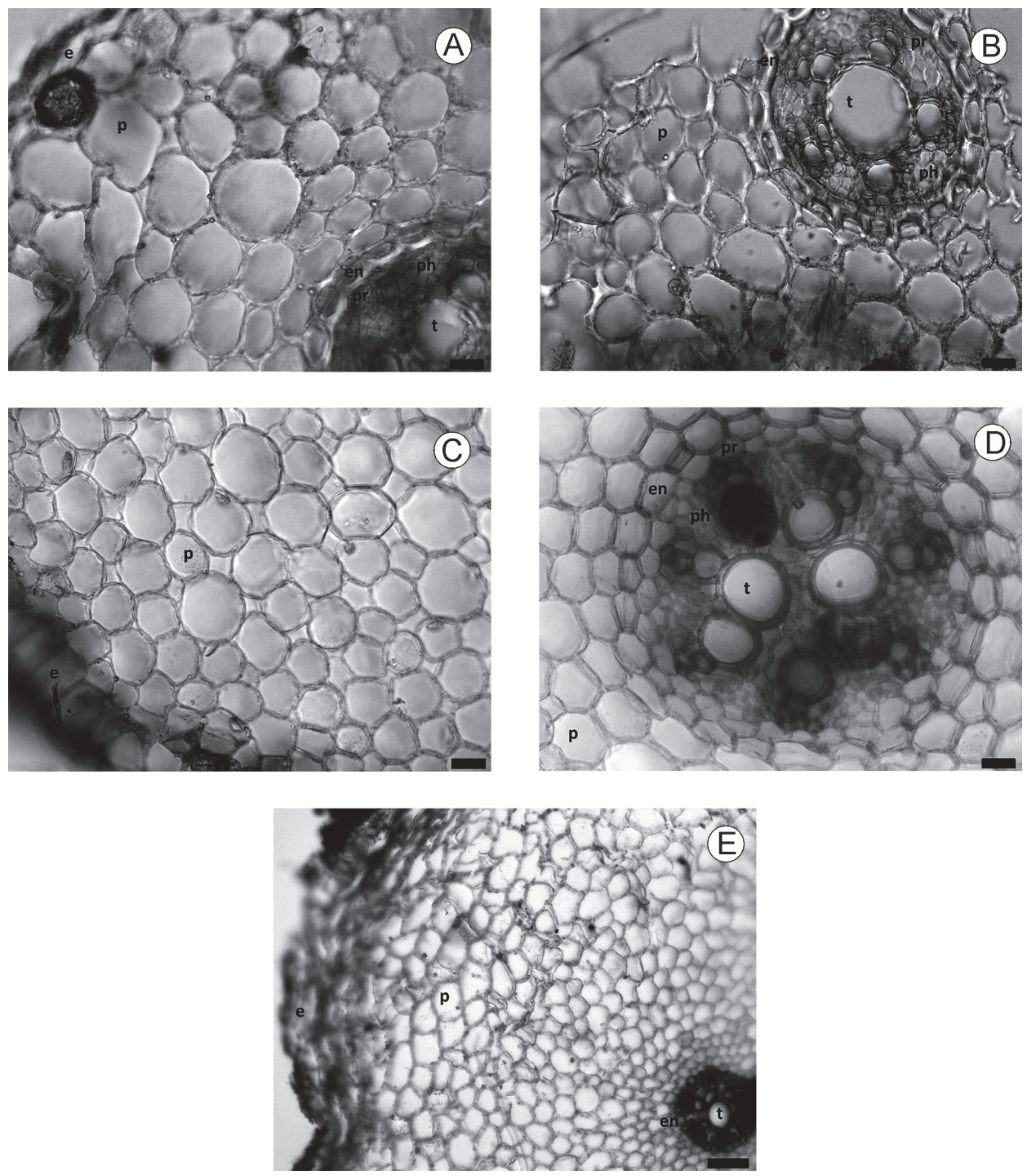

Fig. 2. The root cross-sections of closely related Iris taxa. $\mathrm{A}-\mathrm{B}=$ I. pamphylica, $\mathrm{C}-\mathrm{D}=$ I. masia subsp. dumaniana, $\mathrm{E}=$ I. masia subsp. masia. Legend: $\mathrm{e}=$ epiderma, $\mathrm{p}=$ parenchyma, en = endoderma, $\mathrm{pr}=$ pericycle, $\mathrm{ph}=$ phloem, $\mathrm{t}=$ trachea. Scale bars for all: $20 \mu \mathrm{m}$ 
long-elliptic, with a long-tapering beak at maturing, carried on a peduncle to $10 \mathrm{~cm}$. Seeds surface irregularly rugose.

Iris masia subsp. dumaniana: Plant $35-70 \mathrm{~cm}$ and rhizomes. Leaves 6-8, exceeding or equalling flowers, $0.3-0.6 \mathrm{~cm}$ width (Fig. 1B, Table 1). Bracts and bracteoles narrow and long attenuate at apex. Flowers solitary, maroonpurple. Lamina of falls ovate, obtuse and standards oblanceolate. Falls and standards densely maroon-purple veined. Style branches narrowly lanceolate, maroon-purple veined and finely dotted. Crests similar to style branches. Capsule cylindrical-ellipsoid and with a short beak.

Iris masia subsp. masia: Plant 35-70 cm long and rhizomes perennial. Scape single flower. Bracts and bracteoles long, attenuate at apex. Leaves 6-8 (Fig. 1C, Table 1). Flowers solitary and violet-blue. Lamina of falls ovate, obtuse, standards oblanceolate and slightly paler than the falls. Style branches purple and narrowly lanceolate. Stigma bilobed and lobes acute. Capsule cylindrical-ellipsoid and with a short beak.

\section{The anatomical properties of the roots of the Iris taxa}

Iris pamphylica: In root cross-section, epidermis is single-layered, large and flat-celled. Cortex parenchyma is 7-9 layered. Parenchyma cells are large, oval-shaped (Fig. 2A). In the cortex, there are idioblasts and crystalline granules. Endodermis and pericycle are single-layered. Endodermis cells are large and flat. The thickness in endodermal cells is three-sided and oriented to pericycle. There is no thickness towards cortex. Xylem has 4-6 strands. In the pith region, there is one large trachea (Fig. $2 B$ ).

Iris masia subsp. dumaniana: The outer surface of the root, epidermis is single-layered and large-celled. Cortex parenchyma is 12-15 layered. Parenchyma cells are large and oval-shaped (Fig. 2C). In the cortex, there are styloids, idioblasts and crystalline granules. Endodermis is single-layered. The thickness in endodermis is not obvious. Pericycle under the endodermis is single-layered. Xylem strands are 6-7. Trachea of xylem is very large. There is a narrow pith region in the centre of the root (Fig. 2D). The pith region consists of small cells with lignified cell wall.

Iris masia subsp. masia: Epidermis is single-layered and large-celled. Cortex is multi-layered (13-15 layered) and parenchymatic. Cortex cells near the endodermis are small. Endodermis and pericycle are single-layered and large-celled. The thickness in endodermis cells are three sided and oriented to pericycle. There is no thickness towards cortex. Xylem has 6-7 strands. There is one large trachea in the pith (Fig. 2E). 

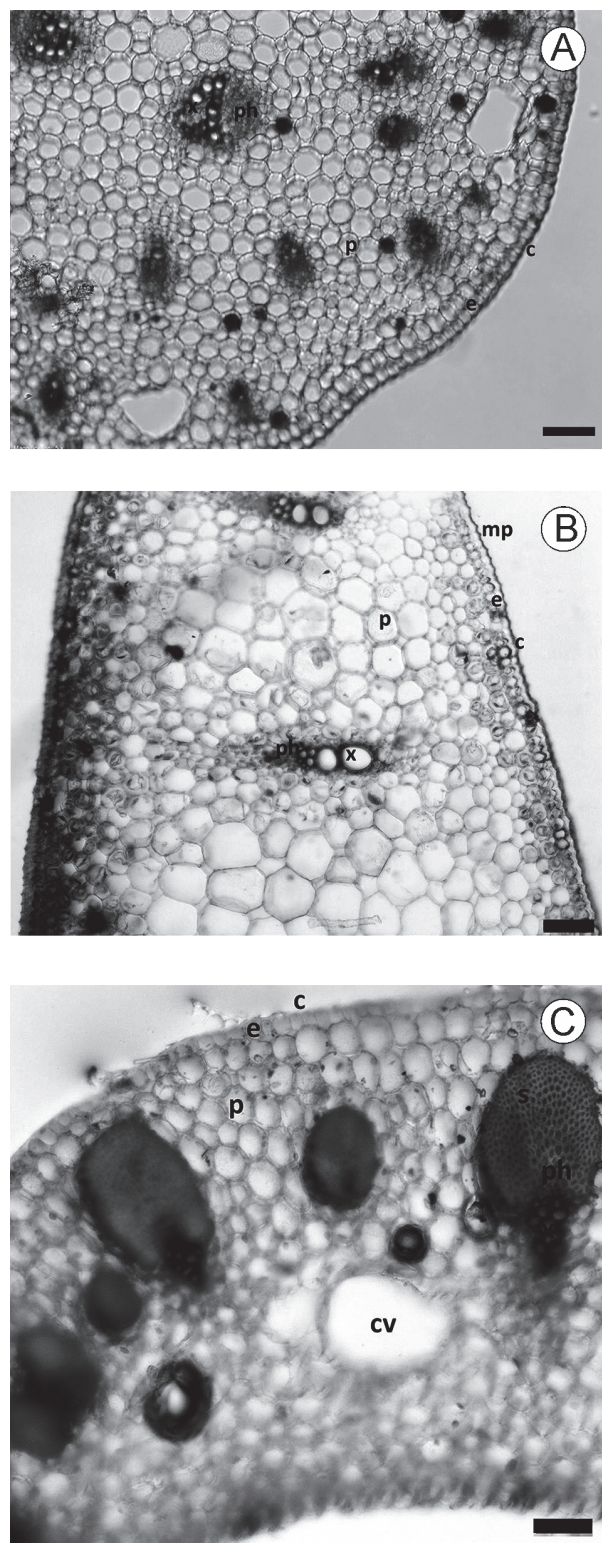

Fig. 3. The scape cross-sections of closely related Iris taxa. $-\mathrm{A}=I$. pamphylica, $\mathrm{B}=I$. masia subsp. dumaniana, $\mathrm{C}=I$. masia subsp. masia $(\mathrm{c}=$ cuticle; $\mathrm{e}=$ epidermis; $\mathrm{p}=$ parenchyma; $\mathrm{s}=$ sclerenchyma; $\mathrm{mp}=$ micropapillae; $\mathrm{ph}=$ phloem; $\mathrm{x}=$ xylem; $\mathrm{cv}=$ cavities). Scale bars for all: $100 \mu \mathrm{m}$
The anatomical properties of the scapes of the Iris taxa

Iris pamphylica: Epidermis is single-layered, small and squareshaped. The cuticle is thin in crosssection of the scape. Papillae and micropapillae are seen on the epidermis and cuticle, respectively. Cortex is composed of oval or circular shaped and small parenchyma cells (Fig. $3 A$ ). The cavities are present in the scape. Vascular bundles are scattered. The vascular bundles in the pith are large, vascular bundles in the outer are small. In the phloem pole of vascular bundles absent sclerenchyma cap. In the pith, parenchyma cells are larger than the cortex parenchyma cells.

Iris masia subsp. dumaniana: In the outer surface of the scape, there is a thick cuticle. Epidermis is singlelayered, small and square-shaped. The dense papillae and serrated micropapillae are seen on the epidermis and cuticle, respectively. Cortex contains oval or circular shaped and large parenchyma cells. There are not cavities and sclerenchymatic cylinder in the cortex. There are dense styloids and idioblast in the cortex. Vascular bundles are in single row and regular (Fig. 3B). The xylem and phloem elements are apparent in the vascular bundles. There is no sclerenchyma cap at the phloem pole. Tracheas are chain-shaped. The pith region consists of large, thin-walled parenchymatic cells.

Iris masia subsp. masia: Epidermis is single-layered, small and square-shaped. The cuticle is thick. 
Micropapillae and papillae are seen on the cuticle and epidermis, respectively. Cortex is composed of circular shaped and large parenchyma cells. In the cortex, there are sparse cavities and dense idioblast. In the cross-section of scape, there are large and small vascular bundles and they are regular. Each bundle is demarcated on the outside by a large cap of phloem sclerenchyma fibres (Fig. 3C).

The anatomical properties of the leaves of the Iris taxa

Iris pamphylica: It has isolateral ensiform type and quadrangular leaves. It has leaves that look like square in cross-section. Epidermis is single-layered, small-celled and oblong shaped. Epidermis cells and cuticle layer were with conic papillae and micropapillae, respectively. Micropapillae on the cuticle layer are extremely conspicuous. Palisade parenchyma is 2-layered and oblong shaped. Spongy parenchyma is 1-2 layered (Fig. 4A). The mesophyll cells in the centre are large, circular shaped and without chloroplast. These cells are broken into pieces. Vascular bundles are two rows. Xylem of vascular bundles is directed towards the leaf centre. Phloem of vascular bundles is directed towards the upper and lower epidermis. They consist of one-layered bundle sheath and these cells are small, without chloroplast. Vascular bundles were lower than the epidermis. There is a large marginal vascular bundle at the corner of leaf. There is sclerenchyma cap (marginal sclerenchyma) only in phloem pole of large bundles and at the corners of the leaf. The marginal sclerenchyma is dense at the leaf corner and extends to epi-

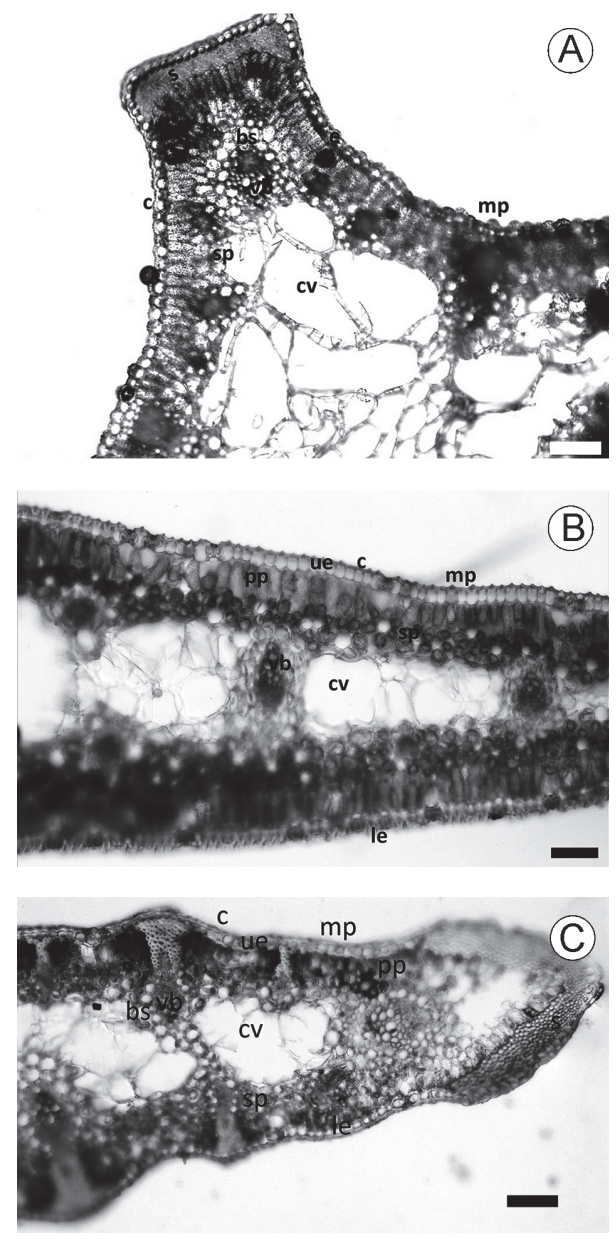

Fig. 4. The leaf cross-sections of closely related Iris taxa. $-\mathrm{A}=I$. pamphylica, $\mathrm{B}=I$. masia subsp. dumaniana, $\mathrm{C}=I$. masia subsp. masia $(\mathrm{c}=$ cuticle; $\mathrm{e}=$ epidermis; ue $=$ upper epidermis; $\mathrm{pp}=$ palisade parenchyma; $\mathrm{sp}$ = spongy parenchyma; $\mathrm{vb}=$ vascular bundles; bs = bundle sheath; $\mathrm{s}=$ sclerenchyma; le = lower epidermis; $\mathrm{mp}=$ micropapillae; $\mathrm{cv}=$ cavities). Scale bars for all: $100 \mu \mathrm{m}$ 
dermis. However, the marginal sclerenchyma in phloem pole is not extends to epidermis. Stomata are rather below the epidermis cells. Stoma is large and ordered. The type of stoma apparatus is tetracytic (Fig. 5A). In mesophyll, crystalline granules are dense, but hexagonal crystals are rare.
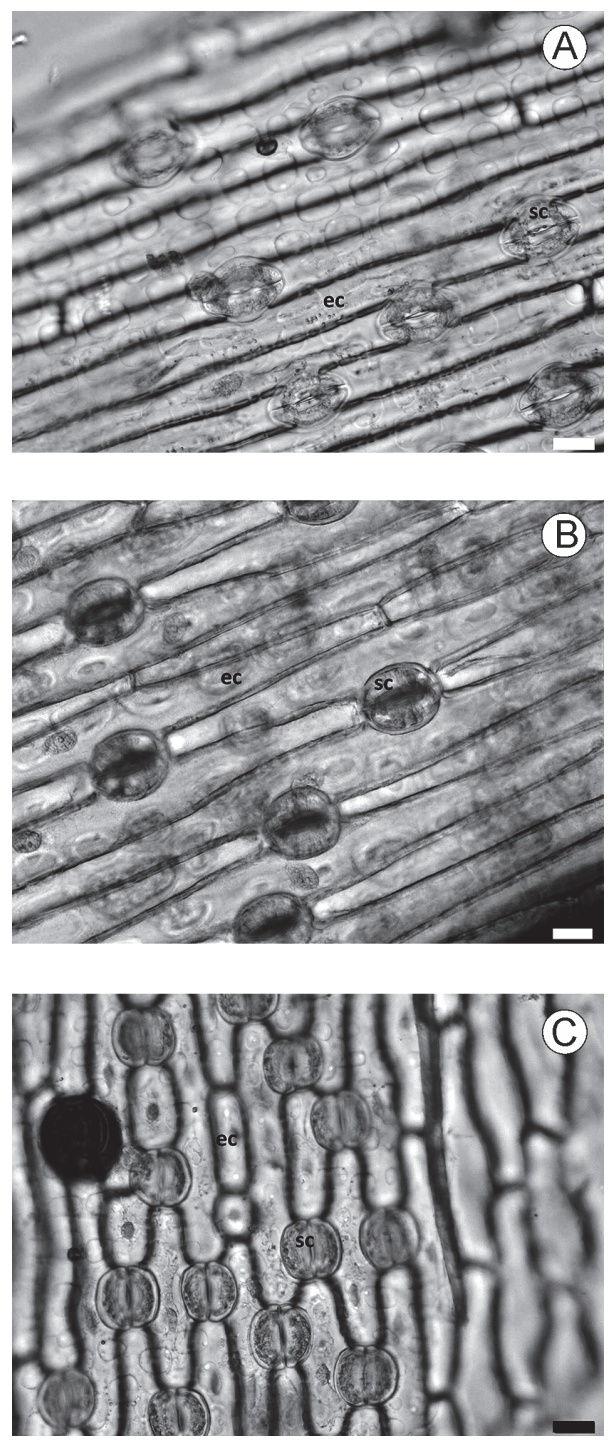

Fig. 5. The leaf surface-sections of closely related Iris taxa. $-\mathrm{A}=I$. pamphylica, $\mathrm{B}=I$. masia subsp. dumaniana, $\mathrm{C}=I$. masia subsp. masia $(\mathrm{ec}=$ epidermis cell; $\mathrm{sc}=$ stoma cell $)$.

Scale bars for all: $20 \mu \mathrm{m}$

Iris masia subsp. dumaniana: Leaf is in isolateral ensiform type (Fig. 4B). Both epidermis cells are square-shaped, large, single-layered and with papillae. Cuticle layer is thick and extremely conspicuous micropapillae. The side walls of upper and lower epidermis cells are wavy. Stoma is large and ordered in both epidermis. They are of tetracytic type (Fig. 5B). Stomata are lower than epidermis cells. Mesophyll is consisted of palisade and spongy parenchyma. The palisade parenchyma is 1-layered in the upper and lower epidermis. These cells are large and with dense chloroplast. The spongy parenchyma is 2-3 layered oval shaped and with less chloroplast. The large cavities and large parenchyma cells are in the centre of mesophyll. Parenchyma in the middle of mesophyll is oval shaped and with less chloroplast. Crystalline granules are less in number in the cavities. Vascular bundles are typically in single layer. Vascular bundles contain bundle sheath one-layered, thin-walled and without chloroplast parenchymatic cells. Sclerenchyma cap is absent at phloem poles of vascular bundles.

Iris masia subsp. masia: Leaf is isolateral ensiform type. Upper and lower epidermis are single-layered and large-celled. Cuticle with micropapillae is thick. There are papillae on the upper and lower epidermis 
(Fig. 4C). Stomata are dense, large and ordered in the upper and lower epidermis. The type of stoma apparatus is tetracytic (Fig. 5C). Stomata are rather below the epidermis cells. There are bulliform cells in the lower and upper epidermis. Mesophyll has 2-3 layered, with dense chloroplast long parenchymatic cells in upper and lower epidermis. Spongy parenchyma is 2-3 layered, oval shaped and with less chloroplast. Parenchyma in the middle of mesophyll is oval shaped and with less chloroplast. Large cavities are observed in the middle of mesophyll. Vascular bundles are arranged in two rows. Large vascular bundles are at margin (large marginal bundles) and keel base (large keel bundles). Small vascular bundles present in the mesophyll regions between two large keel bundles. There is a large marginal vascular bundle at the corner of leaf. Dense sclerenchyma cap is at phloem pole and at the corner of leaf. The sclerenchyma cap is V-form and extends to epidermis. The keels in the both epidermis are more little rounded. Bundle sheaths are one-layered, thin-walled and large parenchymatic cells. While xylem of vascular bundles is directed towards the leaf centre, phyloem of vascular bundles is directed towards upper and lower epidermis.

\section{DISCUSSION}

Relationships among Iris pamphylica, I. masia subsp. masia and subsp. $d u-$ maniana were investigated. These taxa are very close to each other morphologically and anatomically. The distinctive and similar morphological characters of the taxa were listed in Table 1. As it is seen in Table 1, some morphological characters such as; length and width of leaf, length of bract and bracteole, size of perianth tube, colour of flowers, length and colour standard and fall, size of style branches and capsule type of I. pamphylica are different from subsp. masia and subsp. dumaniana. Also, I. pamphylica is distinguishable by its flower colours, short perianth tube and fruiting characters. Only, differences in falls, standard and style colours and vein colour of subsp. masia and subsp. dumaniana are seen. Based on the falls, standards and styles colours and vein colours, I. masia was distinguished as subsp. dumaniana and subsp. masia by Güner (2012). While the subsp. masia has flowers navy blue and violet-purple, subsp. dumaniana has maroon-purple flowers. Falls, standards and style branches of subsp. dumaniana are densely maroon-purple veined and finely dotted. The crests are similar to style branches. Apart from some exceptions, such as flower characters of the two subspecies, other morphological characters are very similar to each other (Table 1).

Anatomy of the roots of these three taxa shows typical monocotyledonous characters. The thickness is clear in the walls of endodermal cells of $I$. pamphylica and subsp. masia. These thickenings are three-sided and oriented 
towards the pericycle. But, the thickness in the walls of endodermal cells of subsp. dumaniana is not apparent. The 6-7 xylem strands were seen in the root of subsp. masia and subsp. dumaniana, while 4-6 xylem strands were seen in the root of I. pamphylica (Table 3). In the pith region of I. pamphylica and subsp. masia, there is one large trachea and is not pith region (Fig. 2B, E). There are small pith cells with lignified cell wall at the centre of the root of subsp. dumaniana (Fig. 2D). The structure of pith region and xylem strands numbers in the roots may use as distinguishing characters among the three taxa. The same phenomenon was found in the roots of some Iris taxa by researchers (Gontova and Zatylnikova 2013, Kandemir and Engin 1998, Kandemir and Yakupoğlu 2016, Kandemir et al. 1996, Koca 1996, Mitić et al. 2000, Nicolić and Mitić 1991). In the scape of I. pamphylica, cuticle was thin and cortex consisted small parenchymatic cells. The cuticle was thick and cortex occurred large parenchymatic cells in the scape of subsp. masia and subsp. dumaniana. The cavities were seen in the scape of I. pamphylica and subsp. masia. However, the cavities were not seen in the scape of subsp. dumaniana. In the scape of three taxa, papillae and micropapillae are observed in the epidermis and cuticle, respectively. But, micropapillae of subsp. dumaniana is denser than the two taxa and serrated structure. While the vascular bundles of I. pamphylica were scattered, the vascular bundles of subsp. masia and subsp. dumaniana were regular. In the phloem pole of vascular bundles of subsp. masia have dense sclerenchyma cap only. There are dense idioblast and styloids in the subsp. dumaniana. Vascular bundles and micropapilla status, the presence of the cavities, idioblast, styloids and sclerenchyma cap in the scapes may be distinguishing anatomical characters among the three taxa. Moreover, subsp. masia and subsp. dumaniana may be easily distinguished with serrated micropapillae and absence and presence of sclerenchyma cap. The similar status was observed in the scapes of some Iris taxa (Kandemir and Engin 1998, Kandemir and Yakupoğlu 2016, Kandemir et al. 1996). Also, Wu and Cutler (1985) reported that the differences in size and shape of styloids were significant among Iris taxa. Styloids in different shapes were seen in Iris taxa by Rudall (1994). The differences in calcium oxalate crystals in the species level are used as distinguished characters by Namba et al. (1991).

Leaves of these taxa have isolateral ensiform type. Some differences were seen in the leaf mesophyll structure of the subgenera of Iris genus in Turkey. According to the anatomical studies, unifacial and bifacial types in the Hermodactyloides subgenus, unifacial type in the Iris subgenus, bifacial type in the Scorpiris subgenus, isolateral type in the Limniris subgenus were recognised (Deniz et al. 2015, Kandemir 2015, Kandemir and Yakupoğlu 2016, Kandemir et al. 1996, Koca 1996). In the upper and lower epidermis of taxa, papillae were seen and papillae has one row per cell. Micropapillae on the 
cuticle of I. pamphylica and subsp. masia are conspicuous. But, micropapillae and papillae of subsp. dumaniana is extremely conspicuous and micropapillae is serrated structure. There are more than one row of micropapillae per cell. Similar results were observed in some taxa of Iridaceae family by Rudall (1994). Stomata are large and in ordered. The type of stomata apparatus are tetracytic in the three taxa (Table 2). Stomata of taxa were rather below in the epidermis cells. More stomata were observed in the upper and lower epidermis of subsp. masia compared to the other two taxa. Stomata in subsp. dumaniana are larger than the other two taxa (Table 2). The mean number of epidermis and stoma cells in $1 \mathrm{~mm}^{2}$ in lower surfaces of the leaves were found to be: 79 and 136, 85 and 130, 72 and 198 in I. pamphylica, subsp. dumaniana and subsp. masia, respectively (Table 2). When the stomata index of these taxa investigated, the highest stomata index value is seen in subsp. masia and the lowest one in subsp. dumaniana in lower epidermis. The biggest stomata is determined in subsp. dumaniana and the smallest ones in subsp. masia. Although taxa are not distinguished by stomata apparatus type, these taxa can be distinguished by dense and length-width measurements of stomata. In upper epidermis of subsp. masia, the bulliform cells were observed. However, in the upper epidermis of subsp. dumaniana and I. pamphylica the bulliform cells were not observed. In mesophyll of I. pamphylica and subsp. masia, there are crystalline granules, hexagonal crystals and large cavities. While sclerenchyma cap is absent at phloem poles of vascular bundles of subsp. dumaniana, there is dense sclerenchyma cap at phloem poles of vascular bundles and at the corner of subsp. masia and I. pamphylica leaf. In the subsp. masia, marginal sclerenchyma extends to epidermis. Subsp. masia has rounded keels in the leaf. However, keels are not seen in the leaf of subsp. dumaniana and I. pamphylica. We think that presence and absence of sclerenchyma cap and keels in the both epidermis have taxonomic value between two subspecies. So, subsp. masia and subsp. dumaniana may be easily distinguished from each other. The sclerenchyma cap was found in some species of Tigridieae (Iridaceae) and Iridaceae family by Rudall (1991, 1994). However, the sclerenchyma cap does not extend to epidermis and extends to epidermis in some taxa of Iridaceae family. Since leaf margin structures are different in the taxa of Iridaceae, these characters were reported to be significant in generic groupings of Iridaceae taxa by Rudall and Goldblatt (1991). Vascular bundles have two rows in I. pamphylica and subsp. masia. Whereas, vascular bundles have only one row in subsp. dumaniana. This situation was seen in other species of Iridaceae family (Kandemir 2015, Kandemir and Yakupoğlu 2016, Rudall 1994). Palisade parenchyma was one-layered in I. pamphylica and subsp. dumaniana, 1-2 layered in subsp. masia. Spongy parenchyma was 1-2 layered in I. pamphylica, 2-3 layered in subsp. masia and subsp. dumaniana (Fig. 4A-C). The 4-angled and 
quadrangular leaf outline structure is an important property for I. pamphylica. These properties were not seen in the subsp. masia and subsp. dumaniana.

In anatomical characters of investigated taxa, some differences, such as the structure of pith region and xylem strands numbers in the roots, vascular bundles and micropapilla status in the scapes, leaf outline structure, the presence of sclerenchyma cap at phloem poles of vascular bundles, extends to both epidermis of sclerenchyma cap, absence and presence of keels, layer numbers of palisade and spongy parenchyma and the presence of bulliform cells in the upper epidermis of leaves were found. The differences were observed especially in central cylinder of roots and scapes, in the leaf outline structure of leaves. We think that these characters may be used as distinguishing taxonomic characters in the classification of the investigated taxa. Nikolić and Mitić (1991), Kandemir (2015) and Kandemir and Yakupoğlu (2016) suggested that anatomical characters of leaves could be significant characters for some Iris species. The similar results were also seen in other Iris taxa (Gontova and Zatylnikova 2013, Kandemir and Engin 1998, Kandemir et al. 1996, Koca 1996, Rudall 1991). Most anatomical characters, such as stomata and mesophyll types, there is sclerenchyma in the vascular bundles and at the corner of the leaf, there is sheath bundle around the vascular bundles, the cells in the centre of mesophyll and crystal types and there are two rows of the vascular bundles in the mesophyll are similar among the three taxa. In investigated taxa, xeromorphic leaf properties were observed, i.e. stomata were below the epidermis cells, mesophyll was in isolateral structure, dense sclerenchyma cap were in the vascular bundles and at the margin and corner of the leaves. These xeromorphic characters were obtained in the other Iris taxa and Scilla taxa (Deniz et al. 2015, Kandemir 2015, Kandemir et al. 2016).

Mathew (1989) reported that I. pamphylica provided connection between subgenera Hermodactyloides and Limniris. Pollen morphology of I. pamphylica shows similarities not only to I. masia but also to the other taxa of the subgenus Limniris (except I. lazica and I. unguicularis). On the other hand, Kandemir (2015) suggested that I. pamphylica has different properties from other species of subgenus Hermodactyloides in terms of leaf anatomical characters. Also, I. pamphylica is different from the species of subgenus Hermodactyloides related to some morphological characters and pollen morphology (Deniz et al. 2015, Mathew 1989). Anatomical and morphological data in this study support that there is very close relationships between the three taxa. Both I. pamphylica and I. masia provide a strong connection between subgenera Limniris and Hermodactyloides. Due to this relationship, the Hermodactyloides subgenus might be accepted as intermediate subgenus of Iris genus. Moreover, Mathew (1989), Mathew and Atay (1998) reported that separation from Iris genus of Hermodactyloides subgenus were unnecessary because of this connection. Relationships 
between subgenera Limniris and Hermodactyloides were seen between subgenera Nepalensis and Scorpiris, Syriacae series of Limniris subgenus and Hermodactyloides subgenus (Rodionenko 1987, Rudall and Mathew 1993). Consequently, there is a close relation between the taxonomic state with anatomical and morphological properties of I. pamphylica and subsp. masia from investigated Iris taxa. As mentioned above, morphological and anatomical characters of subsp. dumaniana are very different from subsp. masia and I. pamphylica. So, we suggest that subsp. dumaniana should be promoted to species category.

\section{REFERENCES}

Algan, G. (1981): The microtechnic for plant tissues. - Firat University Press, Turkey.

Deniz, I. G., Aykut, C. and Başaran, M. A. (2015): Taxonomic and ecologic properties of the endangered Iris pamphylica (Iridaceae) endemic to S. W. Anatolia. - J. appl. biol. sci. (JABS) 9(2): 1-6.

Gontova, T. N. and Zatylnikova, O. A. (2013): Comparative morphological and anatomical study of leaves and stem of Iris pseudocorus and I. sibirica. - Int. J. Pharm. Pharmaceut. Sci. 5(3): 574-578.

Guo, J. and Wilson, C. A. (2013): Molecular phylogeny of crested Iris based on five plastid markers (Iridaceae). - Syst. Bot. 38: 987-995. https://doi.org/10.1600/036364413x674724

Güner, A. (2012): Iris L. - In: Güner, A. et al. (eds): Turkey plants list (vascular plants). Nezahat Gökyiğit Botanical Garden and Flora Research Association Publication, İstanbul, pp. 535-540.

Kandemir, N. (2015): Leaf anatomical properties of some rare and endemic Iris L. taxa and their reletions: subgenus Hermodactyloides in Turkey. - Iran. J. Bot. 21(2): 142-151.

Kandemir, N. and Engin, A. (1998): Comparative and morphological and anatomical study on some endemic Iris L. species (Iridaceae). - XIV National Congress of Biology, plant physiology, plant anatomy and hydrobiology sections, Samsun, Volume II, pp. 401-414.

Kandemir, N. and Yakupoğlu, H. (2016): Morphological and anatomical properties of endemic Iris nezahatiae distributed in the North-East Anatolia region (Turkey). - BEU J. Sci. 5(1): 104-112. https://doi.org/10.17798/beufen.97630

Kandemir, N., Çelik, A. and Ermiş, A. (2016): Comparative leaf and scape anatomy of some Scilla taxa in Turkey. - Int. J. Agric. Biol. 18(5): 957-964. https://doi.org/10.17957/ ijab/15.0191

Kandemir, N., Şenel, G., Engin, A. and Özkan, M. (1996): A comparative study morphological and anatomical on Iris pseudocorus L. and I. germanica L. species (Iridaceae). - XIII National Congress of Biology, İstanbul, pp. 461-470.

Koca, F. (1996): Morphological and anatomical studies on some endemic Iris L. species (Sect. Iris) in Turkey. - Turk. J. Bot. 20 (Suppl.): 43-57.

Mathew, B. (1984): Iris L. - In: Davis, P. H. (ed.): Flora of Turkey and the East Aegean Islands. Edinburgh University Press, Edinburgh, Vol. 8, pp. 382-410.

Mathew, B. (1989): A taxonomic revision of Iris subgenus Hermodactyloides (Iridaceae). - In: Tan, K. (ed.): Plant taxonomy, phytogeography and related subjects. Edinburgh University Press, Edinburgh, pp. 81-109.

Mathew, B. (2001): Some aspects of the Juno group of irises. Proceedings of the International Iridaceae conference. - Ann. Bot., n. ser. 1: 113-122. 
Mathew, B. and Atay, S. (1998): Some interesting observations on I. pamphylica. - The Karaca Arboretum Magazine 4: 167-172.

Meidner, H. and Mansfield, T. A. (1968): Physiology of stomata. - McGraw-Hill, London, 176 pp.

Mitić, B., Nikolić, T. and Liber, Z. (2000): Morphological and anatomical in Alpine-Dinaric populations of the genus Iris L., Pallidae series (A. Kern.) Trinajstić (Iridaceae). - Acta Soc. Bot. Pol. 69(4): 285-291. https://doi.org/10.5586/asbp.2000.038

Namba, T., Komatsu, K., Liu, Y.-P. and Mikage, M. (1991): Pharmacognostical studies on the Polygonatum plants. I. On the Tibetan crude drug "Ra-mNye". - Shoyakugaku Zasshi 45: 99-108.

Nikolić, T. and Mitić, B. (1991): Phenetic relationships within populations of Iris illyrica, I. pallida and I. peudopallida (Iridaceae) with regard to morphological characteristics of epidermis. - Acta Bot. Croat. 50: 99-106.

Rahman, A.-U., Nasim, S., Baig, I., Jalil, S., Orhan, I., Sener, B. and Choudhary, M. I. (2003): Anti-inflammatory isoflavonoids from the rhizomes of Iris germanica. - J. Ethnopharmacol. 86: 177-180. https://doi.org/10.1016/s0378-8741(03)00055-2

Rodionenko, G. I. (1987): The genus Iris. - The British Iris Society, London, 222 pp.

Rudall, P. (1991): Leaf anatomy in Tigridieae (Iridaceae). - Plant Syst. Evol. 175: 1-10. https://doi.org/10.1007/bf00942141

Rudall, P. (1994): Anatomy and systematics of Iridaceae. - Bot. J. Linn. Soc. 114: 1-21. https:// doi.org/10.1111/j.1095-8339.1994.tb01920.x

Rudall, P. and Goldblatt, P. (1991): Leaf anatomy and phylogeny of Ixioideae (Iridaceae). Bot. J. Linn. Soc. 106: 329-345. https://doi.org/10.1111/j.1095-8339.1991.tb02297.x

Rudall, P. and Mathew, B. (1993): Leaf anatomy of the bulbous irises. - Bot. Jahrb. Syst. 115: 63-76.

Wilson, C. A. (2004): Phylogeny of Iris based on chloroplast matK gene and trnK intron sequence data. -Mol. Phyl. Evol. 34: 402-412. https://doi.org/10.1016/j.ympev.2004.06.013

Wilson, C. A. (2009): Phylogenetic relationships among the recognized series in Iris section Limniris. - Syst. Bot. 34(2): 277-284. https://doi.org/10.1600/036364409788606316

Wilson, C. A. (2011): Subgeneric classification in Iris re-examined using chloroplast sequence data. - Taxon 60: 27-35.

Wilson, C. A. (2014): The complete plastid genome sequence of Iris gatesii (Section Oncocyclus) a bearded species from southeastern Turkey. - Aliso 32: 47-54. https://doi. org/10.5642/aliso.20143201.03

Wilson, C. A., Padiernos, J. and Sapir, Y. (2016): The royal irises (Iris subg. Iris sect. Oncocyclus): plastid and low-copy nuclear data contribute to on understanding of their phylogenetic relationships. - Taxon 65(1): 35-46. https://doi.org/10.12705/651.3

Wu, Q.-G. and Cutler, D. F. (1985): Taxonomic, evolutionary and ecological implications of the leaf anatomy of rhizomatous Iris species. - Bot. J. Linn. Soc. 90: 253-303. https:// doi.org/10.1111/j.1095-8339.1985.tb00385.x 